\title{
Development of clade- (Roseobacter and Alteromonas) and taxon-specific oligonucleotide probes to study interactions between toxic dinoflagellates and their associated bacteria
}

\author{
ROBIN BRINKMEYER ${ }^{1}$, MICHAEL RAPPÉ ${ }^{2 *}$, SUSAN GALLACHER $^{3}$ AND LINDA MEDLIN ${ }^{1}$ \\ ${ }^{1}$ Alfred-Wegener-Institute für Polar- und Meeresforschung, Am Handelshafen 12, D-27570 Bremerhaven, Germany \\ ${ }^{2}$ Station Biologique, Centre National de la Recherche Scientifique et Université Pierre et Marie Curie, BP 74 29682, Roscoff Cx, France \\ ${ }^{3}$ FRS Marine Laboratory, PO Box 101, Victoria Road, Aberdeen AB11 9DB, Scotland, UK
}

(Received 14 July 2000; accepted 20 August 2000)

\begin{abstract}
Bacteria associated with toxic algae in culture have been implicated in the enhancement of algal toxin production and auto-toxigenesis. Toxigenic and non-toxigenic bacterial isolates from Alexandrium spp. have been determined to belong predominantly to the $\alpha$ - and $\gamma$ subclasses of the class Proteobacteria. Within these subclasses, the isolates were further classified into two clades that were phylogenetically affiliated with (1) the genus Roseobacter, a newly identified group that is of major significance within the $\alpha$-Proteobacteria and (2) the genus Alteromonas. Specific 16S rRNA sequence signatures were identified for these clades as well as for three pairs of isolates and for one subcluster within the Roseobacter clade and for three clusters representing eight isolates in the Alteromonas clade.

Oligonucleotide probes complementary to these regions were designed and their specificities were tested using dot-blot and whole-cell in situ hybridizations of target and non-target strains. The empirically determined dissociation temperatures of the probes ranged between 55 and 65 making them applicable as a set for screening environmental samples. In situ hybridization of bacteria in cultures of Alexandrium spp. with the clade-specific probes showed a loose association of these bacteria within the phycosphere. In addition, the fluorescent signal of the probes was bright and easily distinguishable from autofluorescent bacteria and the dinoflagellates.
\end{abstract}

Key words: Alexandrium, Alteromonas, bacteria, FISH, oligonucleotide probes, Roseobacter, toxic algae

\section{Introduction}

The association of bacteria with toxic algal species in culture has been frequently documented (Silva, 1962; Tosteson et al., 1989; Rausch de Traubenberg \& Lassus, 1991; Doucette, 1995; Doucette \& Trick, 1995; Lafay et al., 1995 ; Franca et al., 1996; Kopp et al., 1997; Stewart et al., 1997; Babinchak et al., 1998; Provic et al., 1998). However, the exact role of bacteria in the association has not been determined. Autonomous production of paralytic shellfish poison (PSP)-like toxins by bacteria associated with toxic algae in culture and enhancement of algal toxigenesis by bacteria has also been reported independently by several researchers (Kodama et al., 1988, 1990; Ogata et al., 1990; Gallacher \& Birkbeck, 1993, 1995; González et al., 1995; Gallacher et al., 1996, 1997; Doucette \& Powell, 1998; Maas et al., 1998). Taxon specificity and/or spatial proximity (attached, endosymbiotic or free-living in the phycosphere) has been demonstrated to be important to the association of toxigenic bacteria with toxic algae in a few cases (Doucette

\footnotetext{
Correspondence to: R. Brinkmeyer. e-mail: rbrinkmeyer@awibremerhaven.de

* Present address: Department of Microbiology, Oregon State University, Corvallis 97331, Oregon, USA.
}

\& Powell, 1998), whereas in others taxon specificity was not an issue and any bacterium re-introduced into the culture increased the toxicity of the algae (Bates et al., 1995). Light and transmission electron microscope observations of bacteria associated with toxic algae have provided some information on spatial proximity (Franca et al., 1996), however, results have been inconsistent and localization of bacteria known to be toxigenic within the algal cells has been problematic (Doucette et al., 1998). Field studies of harmful algal blooms (HABs) and their bacterial flora have focused primarily on successional composition of and possible inhibition or stimulation of blooms by associated bacteria (Buck \& Pierce, 1989; Romalde et al., 1990; Fukami et al., 1991a, b; Onji et al., 1995; Ishida et al., 1997). Qualitative composition of bacteria in these studies was determined by isolation, followed by morphological, physiological and biochemical tests and, more recently, RFLP analyses of $16 \mathrm{~S}$ rDNA. Despite the intensive efforts of these methods, an ecological 'snapshot' providing simultaneous data of species composition, abundance and interaction of bacteria with toxic algae during a bloom event is not yet available.

Since the pioneering papers of Giovannoni et al. (1988), DeLong et al. (1989), Amann et al. (1990, 1992), and Manz et al. (1992), the application of whole-cell in situ 
hybridization to the study of microbial distribution (Glöckner et al., 1996; Ramsing et al., 1996) and succession of populations (Bruns \& Berthe-Corte, 1998; Pernthaler et al., 1998) in the environment has increased rapidly. $16 \mathrm{~S}$ rDNA oligonucleotide probing of bacteria in toxic algal cultures and HABs would provide qualitative as well as quantitative information necessary to understand bacterial/toxic algal associations and HAB ecology. Questions of taxon specificity, localization and environmental distribution of bacteria associated with HABs can be readily answered with oligonucleotide probing. In one of the first applications of in situ hybridization probing of toxic algal cultures, Babinchak et al. (1998) used fluorescently labelled, universal and class-specific $16 \mathrm{~S}$ rDNA oligonucleotide probes to examine bacteria in cultures of Alexandrium spp. The most dominant classes of bacteria found were from the $\alpha$ - and $\gamma$-subclasses of the Proteobacteria.

In the current study, 16S rDNA oligonucleotide probes have been developed to detect and localize toxigenic and non-toxigenic bacteria in cultures of Alexandrium spp. The bacterial strains examined were isolated from cultures of Alexandrium tamarense, A. lusitanicum and $A$. affine by Gallacher et al. (1997). Based on 16S rRNA gene sequence analyses, isolated bacteria predominantly represented two distinct phylogenetic clades related to the genera Roseobacter ( $\boldsymbol{\alpha}$-subclass Proteobacteria) and Alteromonas ( $\boldsymbol{\gamma}$-subclass Proteobacteria) (S. Gallacher, E. Mass, E. Moore, \& G. Hold, unpublished data). Clade-, subclade- and isolatespecific probes were identified. As part of a continuing project to determine the localization of bacterial cells associated within the phycosphere of toxic algae and to determine the abundance and distribution of these bacteria in HABs, the presence of these bacteria throughout one PSP season will be presented in an accompanying paper (Töbe et al., in press). This paper presents development and specificity testing of these probes.

\section{Materials and methods}

\section{Oligodeoxynucleotide probes}

E. Moore (GBF, Germany) provided 16S rRNA gene sequences of the bacterial strains used in this study. Sequences were manually aligned in a bacterial database containing over 600 published and unpublished bacterial sequences representing a subset of the bacterial alignment provided by the Ribosomal Database Project (RDP; Maidak et al., 1999) using maximum primary and secondary structural similarity with the Olsen sequence editor (Larsen et al., 1993). This subset of the RDP alignment contained one or two representatives from each of the taxonomic entries provided in the bacterial taxonomic list from the RDP. Data sets of 29 and 45 species were produced from this alignment for phylogenetic analyses of the Alteromonas and Roseobacter clades, respectively. Masks of 1399 and 1076 nucleotides were used for the Alteromonas and Roseobacter data sets, respectively, using Escherichia coli as the outgroup for the Alteromonas data set and the 16S rRNA sequence from Azospirillum lipoferum (Z29619), Rhodovibrio salinarum (M59069) and Rhodocista centenaria (D12701) for the Roseobacter data set. Maximum likelihood analyses were performed using the fastDNAml program (v. $1 \cdot 0)$ with a transition/transversion ratio generated from each of the data sets individually by the fastDNAml program (Larsen et al., 1993) and random taxon addition. Introduced gaps were treated as missing data. Distance analyses were performed using the PHYLIP computer program package (Felsenstein, 1993). Dissimilarity values (Fitch \& Margoliash, 1967), based on pairwise comparisons of sequences, were transformed into distances using the Kimura twoparameter model (Kimura, 1980). Distance matrices were converted into dendograms using the neighbour-joining method (Felsenstein, 1993). Stability of monophyletic groups in distance trees was estimated with a bootstrap analysis (500 replicates) (Felsenstein, 1985).

Clade- and taxon-specific oligonucleotide probes were designed from a database containing $16 \mathrm{~S}$ rRNA sequences imported from RDP as described and unpublished sequences using the PROBE-DESIGN tool of ARB (Strunk et al., 1998). Secondary structure predictions (i.e. selfcomplementation and exergonic properties) were then calculated using the DNASIS (version 2.1, Hitachi Software Engineering) and OLIGO programs (version 4.0, Hitachi, Japan). Probes exhibiting minimal (two GC bonds or fewer) self-complementation were subsequently analysed for specificity using the PROBE MATCH tool of the RDP (Maidak et al., 1999), Advanced BLAST (Altschul et al., 1990) and a database containing over 10000 published and unpublished bacterial $16 \mathrm{~S}$ rRNA sequences (M. Rappé, unpublished data). Additional strain sequences with up to five mismatches to the probe sequence, which were highlighted in our probe searches, were downloaded from GenBank (Benson et al., 1999) and entered into our database for further comparison.

C. Lazarus (University of Bristol, UK) synthesized unlabelled probes which were digoxigenin DIG-dUTP labelled in our laboratory using the DIG Oligonucleotide Tailing Kit (Boehringer-Mannheim, Mannheim, Germany) according to the manufacturer's instructions. Fluorescein and CY3 (5') labelled probes were synthesized and HPLCpurified by Interactiva (Ulm, Germany). In addition, the universal eubacterial probe EUB338R was used as a positive control and the nonsense probe NON338 as a negative control (Manz et al., 1992). Probe names followed the format: bacterial strain number/E. coli position number/R, except for the two clade probes, for which we also could provide a probe name following the oligonucleotide probe database protocol (Alm et al., 1996).

\section{Bacteria and growth conditions}

The bacterial strains used in this study for probe testing were isolated by Gallacher et al. (1997) from toxic strains 
of A. tamarense (NEPCC 407 and UW2C $=$ toxic UK Scottish strain from $\mathrm{Dr}$ Jane Lewis, University of Westminster), A. lusitanicum (NEPCC253) and A. affine (NEPCC667). Bacterial strains used for specificity testing were obtained from the Deutsche Sammlung von Mikroorganismen und Zellkulturen (DSMZ, Braunschweig, Germany) and are listed in Tables 1 and 2. Additional strains used for testing but not listed in Tables 1 and 2 are Ruegeria algicola (formerly Roseobacter algicola; Uchino et al., 1998) DSM10251, Roseobacter denitrificans DSM7001 and Roseobacter litoralis DSM6996. Strains, with the exception of Clostridium proteolyticum, were grown in ASG medium (Haygood \& Nealson, 1985) at $25^{\circ} \mathrm{C}$ or under culture conditions as recommended by the DSMZ catalogue.

\section{DNA extraction and cell fixation}

Cells were harvested at the exponential growth phase for DNA extraction and for fixation prior to in situ hybridization. Nucleic acids were extracted using a $3 \%$ CTAB (hexadecyltrimethylammonium bromide) procedure (Doyle \& Doyle, 1990). Nucleic acids of C. proteolyticum were extracted directly from the lyophilized pellet supplied by the DSMZ. Cells harvested for in situ hybridization were washed with $4{ }^{\circ} \mathrm{C}, 0.2 \mu \mathrm{m}$ filtered, $1 \times$ phosphate-buffered saline (PBS) and resuspended in $4{ }^{\circ} \mathrm{C}, 0.2 \mu \mathrm{m}$ filtered, $4 \%$ paraformaldehyde in $1 \times$ PBS (Stahl \& Amann, 1991). Cells were fixed overnight at $4{ }^{\circ} \mathrm{C}$, washed and resuspended in $1 \times$ PBS. We found that overnight fixation rather than the generally practised 2-4 h fixation significantly enhanced signal of the fluorescently labelled oligonucleotide probes. For longterm storage (up to 6 months) at $-20^{\circ} \mathrm{C}$, cells were resuspended in 1:1, $1 \times$ PBS: $96 \%$ ethanol. No noticeable deterioration of fluorescent signal was observed (Stahl \& Amann, 1991). Samples of Alexandrium spp. cultures were similarly fixed with paraformaldehyde and subsequently stored at $4{ }^{\circ} \mathrm{C}$ in $80 \%$ ethanol (repeatedly refreshed) for several days to extract the autofluorescent chlorophyll.

\section{$P C R$ and dot-blot hybridizations}

PCR (Saiki et al., 1988), with the bacterial-specific amplification primer pair $8 \mathrm{~F}$ and $1542 \mathrm{R}$, was used to amplify double-stranded rDNA (Edwards et al., 1989) using the conditions defined in Kopp et al. (1997). PCR-amplified genes were checked for purity and length by electrophoresis in $0.75 \%$ agarose gels. PCR products, $1 \mu \mathrm{l}(c$. $100 \mathrm{ng}$ ), were applied to positively charged nylon membrane-filters (Boehringer-Mannheim), and hybridized with $0.2 \mathrm{pmol}$ of $5^{\prime}$-digoxygenin-labelled probe at the appropriate mid-point dissociation temperature $\left(T_{d}\right)$ for each probe as previously described by Simon et al. (1997). $T_{\mathrm{d}}$ was estimated a priori using the Lathe (1985) formula (Ramsing et al., 1993). Optimal $T_{d}$ for probe specificity was determined empirically. Hybridized probes were detected with chemiluminescence (DIG luminescent detection kit for nucleic acids with CSPD as a substrate, BoehringerMannheim) according to the manufacturer's instructions. Membrane filters were exposed to X-ray films (Amersham, Arlington Heights, IL) for $2-5 \mathrm{~h}$ to visualize the chemiluminescent reactions. For data presentation purposes, exposed X-ray films were scanned with a trans-illuminating scanner and edited with Adobe PhotoShop 4.0.

\section{Fluorescent in situ hybridization (FISH)}

Fixed-cell suspensions (10 $\mu \mathrm{l}$ ) containing either a single bacterial strain or several strains in combination were applied to Teflon-coated hybridization slides (Paul Marienfeld, Bad Mergentheim, Germany) that had been pretreated with gelatin (Stahl \& Amann, 1991). Suspensions, applied to the centre of each hybridization well, were spread with a pipette tip, air-dried and dehydrated in an ethanol series $(50 \%, 80 \%$ and $96 \%$ aqueous ethanol, v/v) (Stahl \& Amann, 1991). Hybridizations were performed in $15 \mu \mathrm{l}$ volumes by application of hybridization buffer (HB) directly to cell smears. Formamide concentration in the HB was estimated a priori using the Lathe (1985) formula modified for formamide addition (Ramsing et al., 1993). Optimal formamide concentration was determined empirically. Probe $(1.5 \mu \mathrm{l})$ hybridizations $\left(2 \mathrm{~h}, 50^{\circ} \mathrm{C}\right)$ and washes (10 min at $50^{\circ} \mathrm{C}$ ) were performed as previously described by Stahl \& Amann (1991). Slides were air-dried in the dark, treated with DAPI $\left(0.001 \mathrm{mg} \mathrm{ml}^{-1}\right.$ final concentration) and mounted in Citifluor (Citifluor, Canterbury, UK). Sealed slides were observed with an Axioscope 20 epifluorescence microscope (Zeiss, Oberkochen, Germany) equipped with filter sets 09 and 14 , for viewing fluorescein and $\mathrm{CY}_{3}$, respectively. Photographs were taken under $\times 1000$ enlargement with 1600 ISO Fuji colour print film following 15-30 s exposure for epifluorescence. Slides were stored at $-20{ }^{\circ} \mathrm{C}$ for up to 3 weeks with no noticeable reduction in fluorescent probe signal.

\section{Nucleotide sequence accession numbers}

The GenBank accession numbers for the sequences of the organisms used to construct the phylogenetic trees are as follows: Staleya guttiformis, Y16427; Roseobacter sp. Shippagan, AF100168; Sulfitobacter pontiacus, Y13155; Roseobacter denitrificans, M59063; Roseobacter litoralis, X78312; Roseobacter sp. Prionitis lanceolata symbiont, U37762; Roseobacter sp. strain QSSC9-8, AF170751; Ruegeria gelatinovorans, D88523; Roseobacter sp. str. DSS-8, AF098493; Octadecabacter antarcticus, U14583; Octadecabacter arcticus, U73725; Roseobacter sp. str. DSS-I, AF098492; Ruegeria atlantica str. IAM 14464, D88527; Silicibacter lacuscaerulensis, U77644; Ruegeria atlantica str. WNA2, AF124521; Roseobacter gallaeciensis, Y13244; Roseobacter sp. str. 303 from Loligo pealei, AF022392; Roseobacter sp. str. J8W, AF026463; Roseovarius tolerans, Y11551; Ruegeria algicola, X78314; Antarctobacter helio- 
Table 1. Roseobacter clade- and taxon/cluster-specific, 16S rRNA oligonucleotide probes and their specificity parameters

\begin{tabular}{|c|c|c|c|c|c|c|c|}
\hline Probe name & OPD name ${ }^{a}$ & $\begin{array}{l}\text { Target species with } \\
\text { zero mismatches }\end{array}$ & Probe sequence $5^{\prime}-3^{\prime}$ & E. coli pos. & $\begin{array}{l}\text { Dot-blot } \\
T_{d}\left({ }^{\circ} \mathrm{C}\right)\end{array}$ & $\begin{array}{l}\% \mathrm{FA} \\
\text { in situ }^{b}\end{array}$ & $\begin{array}{l}\text { Non-target species with } 5 \text { or fewer mismatches used } \\
\text { for specificity testing (no. of mismatches) }\end{array}$ \\
\hline ROSEO536R & $\begin{array}{l}\text { S- }^{*}-\text { ROSEO- } \\
\text { 0536-a-A-18 }\end{array}$ & Roseobacter clade & CAACGCTAACCCCCTCCG & $536-553$ & 65 & $15-18$ & $\begin{array}{l}\text { C116-18 * (1), Paracoccus aminophilus, DSM8538 (1), Paracoccus denitrificans, } \\
\text { DSM65 (1), Caulobacter subvibrioides, DSM4735 (2), Erythrobacter longus, } \\
\text { DSM6997 (2), Erythrobacter litoralis, DSM8509 (2), 4VaS17* (3), 407-2 } \\
\text { and } 4 \alpha \mathrm{VS}^{*} \text { (4) }\end{array}$ \\
\hline ROSEOC536R & $\begin{array}{r}\text { S- }{ }^{*}-\mathrm{ROSEOC}- \\
0536-\mathrm{a}-\mathrm{A}-18\end{array}$ & & CAACGCTAGCCCCCTCCG & $536-553$ & 65 & $15-18$ & $\begin{array}{l}\text { Roseobacter competitor probe matches non-target bacterial strains with } 1 \\
\text { mismatch to the ROSEO536R probe }\end{array}$ \\
\hline $667-12 / 191 R$ & $\mathrm{~N} / \mathrm{A}$ & 667-12 cluster & GGGCTAATCCTTCCTTCССС & $191-235$ & 65 & 20 & Paracoccus denitrificans, DSM65 (4) \\
\hline $667-12 / 994 R$ & N/A & Isolates $667-9$ and $667-12$ & GGAGCGACGACAAGTATGT & $994-1011$ & 60 & 20 & Marinilabilia salmonicolor, DSM6580 (2) \\
\hline 253-11/1423R & N/A & Isolates $253-11$ and $253-13$ & ACCGTCGTCGGGTAGACC & $1423-1440$ & 60 & 0 & $\begin{array}{l}\text { Paracoccus aminophilus, DSM8538 (2), Paracoccus denitrificans, DSM65 (2), } \\
667-4 \text { and } 6,667-19^{*}(3) 667-9 \text { and } 12^{*}(4)\end{array}$ \\
\hline
\end{tabular}

${ }^{a}$ The Oligonucleotide Probe Database (Alm et al., 1996).

${ }^{b}$ Percentage formamide in whole-cell in situ hybridization buffer, incubation $50{ }^{\circ} \mathrm{C}$.

${ }^{*}$ Isolates from this study. N/A = not applicable

Table 2. Alteromonas clade- and taxon-specific $16 \mathrm{~S}$ rRNA oligonucleotide probes and their specificity parameters

\begin{tabular}{|c|c|c|c|c|c|c|c|}
\hline Probe Name & OPD name $^{a}$ & $\begin{array}{l}\text { Target species with } \\
\text { zero mismatches }\end{array}$ & Probe sequence $5^{\prime}-3^{\prime}$ & E. coli pos. & $\begin{array}{l}\text { Dot-blot } \\
T_{\mathrm{d}}\left({ }^{\circ} \mathrm{C}\right)\end{array}$ & $\begin{array}{l}\% \mathrm{FA} \\
\text { in situ }^{b}\end{array}$ & $\begin{array}{l}\text { Non-target species with } 5 \text { or fewer mismatches used } \\
\text { for specificity testing (no. of mismatches) }\end{array}$ \\
\hline AC137R & S-*-AMAC-0137-a-A-18 & Alteromonas clade & TGTTATCCCCCTCGCAAA & $137-154$ & 60 & 10 & $\begin{array}{l}\text { Pseudoalteromonas denitrificans, DSM6059 (4), Shewanella baltica, } \\
\text { DSM9439 (5) }\end{array}$ \\
\hline $407-2 / 209 \mathrm{R}$ & $\mathrm{N} / \mathrm{A}$ & Isolates $407-2,407-5$ and $407-6$ & CTTTGCGTGGGAGCCGG & $209-227$ & 65 & 10 & Alteromonas macleodii, DSM6062 (2), 253-19 and 20* (3) \\
\hline $4 \alpha \mathrm{VS} 3 / 210 \mathrm{R}$ & $\mathrm{N} / \mathrm{A}$ & Isolates $4 \alpha \mathrm{VS} 3,2 \mathrm{C} 3$ and $2 \mathrm{C} 6$ & TCTCTTTGCGCCAGAGCT & $210-230$ & 60 & 10 & $\begin{array}{l}\text { Alteromonas macleodii, DSM6062 (2), 253-19 and } 20^{*}(2), 407-2,5 \text {, and } \\
6^{*}(4)\end{array}$ \\
\hline 253-19/175R & N/A & Isolates $253-19$ and $253-20$ & CAAGTGCACATTATGCGG & $175-188$ & 55 & 10 & Clostridium proteolyticum, DSM3090 (4) \\
\hline
\end{tabular}

${ }^{a}$ The Oligonucleotide Probe Database (Alm et al., 1996).

${ }^{b}$ Percentage formamide in whole-cell in situ hybridization buffer, incubation $50{ }^{\circ} \mathrm{C}$.

${ }^{*}$ Isolates from this study. N/A, not applicable. 
thermus, Y11552; Sagittula stellata, U58356; Roseobacter sp. str. LFR, L15345; Roseobacter sp. str. QSSC9-5, AF170750; Marinosulfonomonas methylotropha, U62894; Paracoccus denitrificans, X69159; Paracoccus aminophilus, D32239; Rhodobacter capsulatus, D16428; Rhodobacter sphaeroides, X53854; Rhodovulum iodosum, Y15011; Maricaulis sp. str. MCS 10, M83807; Shewanella putrefaciens ATCC 8071, X82133; Shewanella putrefaciens LMG 26268T, X81623; Shewanella sp., AF005269; Pseudoalteromonas denitrificans, X82138; Vibrio marinus, X82142; Pseudoalteromonas haloplanktis, X67024; Pseudoalteromonas nigrifaciens, X82146; Pseudoalteromonas sp., U85859; Pseudoalteromonas atlantica, X82134; Colwellia psychroerythraea, AF001375; Alteromonas macleodii str. CH-460, Y18233; Alteromonas macleodii, clone 1B161, Y18231; Alteromonas macleodii, clone 17B161, Y18229; Alteromonas macleodii, str. CH-516, Y18234; Alteromonas macleodii, X82145; unidentified gamma Proteobacterium, str. HTC032, AB010857; unidentified gamma Proteobacterium, str. HTC036, AB010855; unidentified gamma Proteobacterium, str. HTC034, AB010844; unidentified gamma Proteobacterium, str. HTC035, AB010856; Alteromonas macleodii, str. DSM6062, Y18228. Accession numbers for the bacterial isolates from dinoflagellates tested in this study (S. Gallacher, E. Mass, E. Moore \& G. Hold, unpublished data) are: 407-20, AJ294353; 667-2, AJ294353; 667-19, AJ294355; 667-4, AJ294354; 667-6, AJ294354; 253-16, AJ294352; 667-12, AJ294356; 667-9, AJ294356; 253-13, AJ294351; 253-11, AJ294351; C11618, AJ294357; 253-20, AJ294362; 253-19, AJ294362; $4 \alpha$ VS3, AJ294361; 2C3, AJ294361; 2C6, AJ294361; 407-6, AJ294360; 407-2, AJ294360; 407-5, AJ294360; and $4 \alpha \mathrm{VS} 17, \mathrm{AJ} 294358$. Identical strains have the same accession number.

\section{Results}

\section{Probe design}

Phylogenetic analyses of 16S rRNA sequences (Olsen, 1988) revealed that most of the bacterial strains isolated from toxic Alexandrium spp. could be classified into two distinct clades: Roseobacter ( $\alpha$-subclass Proteobacteria) or Alteromonas ( $\gamma$-subclass Proteobacteria) (S. Gallacher, E. Mass, E. Moore \& G. Hold, unpublished data). 16S rRNA gene sequences from bacterial strains having $90 \%$ or greater similarity to either Roseobacter denitrificans or Alteromonas macleodii were downloaded from GenBank and used to define these clades further for probe design. Clade-specific oligodeoxynucleotide probes were designed for the Roseobacter and Alteromonas clades, respectively. Additionally, taxon/cluster-specific probes were designed for each of the three pairs of bacterial strains plus one subcluster determined to be within the Roseobacter clade and three taxon-specific probes were designed for bacterial strains represented by eight isolates falling within the Alteromonas clade (Figs 1, 2). Probe sequences are presented in Tables $I$ and 2. Probe
ROSEO536R showed $100 \%$ similarity to 117 of 124 known 16S rRNA sequences determined to be in the Roseobacter clade. I6S rRNA sequences of the Roseobacter clade bacteria that did not show $100 \%$ similarity to the ROSEO536R probe include (1) Roseobacter sp. Shippagan (1C/U mismatch, helix bond maintained) (AF100168), (2) Sulfitobacter pontiacus (1 G/U mismatch, helix bond maintained, non-canonical pairing) (Sorokin 1995; Y13155), (3) Roseobacter sp. DSS-I (1 G/A mismatch, helix bond not maintained) (González et al., 1999; AF098492), (4) Roseobacter sp. QSSC9-8 (1 G/A mismatch, helix bond not maintained) (AF170751), (5) Roseobacter sp. J8W (2 mismatches, C/G, G/A, helix bond not maintained) (Kaufman et al., unpublished data; AF026463), (6) uncultured bacterium Taynaya-15 (1 G/A mm, helix not affected) (AF142961) and (7) Prionitis lanceolata gall symbiont (1 N/G mismatch, undetermined base) (Ashen \& Goff, 1996; U37762).

Probe ROSEO536R also showed $100 \%$ similarity to the $16 \mathrm{~S}$ rRNA sequence of Rhodovulum iodosum (Straub et al., 1999; IY15011), which is not associated with the Roseobacter clade. At least one mismatch to the ROSEO536R probe sequence was found after searching all non-target eubacterial and archaebacterial $16 \mathrm{~S}$ and $23 \mathrm{~S}$ sequence data accessible through the RDP (Maidak et al., 1999) and GenBank internet databases. A competitor probe (ROSEOC536R) recognizing this single and consistent mismatch was used in all hybridization experiments in conjunction with probe ROSEO536R to maximize probe specificity of ROSEO536R by blocking this binding site of those species containing the single mismatch (Amann et al., 1990 and references therein).

Probe AMAC137R showed $100 \%$ similarity to all $16 \mathrm{~S}$ rRNA sequences determined to be in the Alteromonas clade. A minimum of four mismatches were found to all accessible non-target eubacterial and archaebacterial $16 \mathrm{~S}$ and $23 \mathrm{~S}$ sequence data. Sequence similarity to $16 \mathrm{~S}$ rRNA sequences was $100 \%$ for species/cluster-specific probes 407-20/1446R, 667-12/191R, 667-12/994R, 25311/1423R, 407-2/209R, 4 $\alpha \mathrm{VS} 3 / 210 \mathrm{R}$ and 253-19/175R and their target bacterial clusters. From 0 to 5 mismatches were found to accessible non-target eubacterial and archaebacterial $16 \mathrm{~S}$ and $23 \mathrm{~S}$ sequence data for these probes. Target and non-target strains with 0 to 5 mismatches in their $16 \mathrm{~S}$ rRNA sequence which were used for specificity testing are listed in Tables 1 and 2. Probe specificity is indicated on the phylogenetic trees (Figs I, 2).

\section{Dot-blot hybridizations}

Dot-blot analyses were conducted first to evaluate stringency conditions required for whole-cell in situ hybridization testing of probe specificity. Optimal $T_{d}$ values of probes, empirically determined, ranged from 55 to $65{ }^{\circ} \mathrm{C}$ (Tables 1,2 ). The specificity of DIG-labelled probes was interpreted as annealing of probe to target rDNA only. Dot-blots were exposed to X-ray film for 


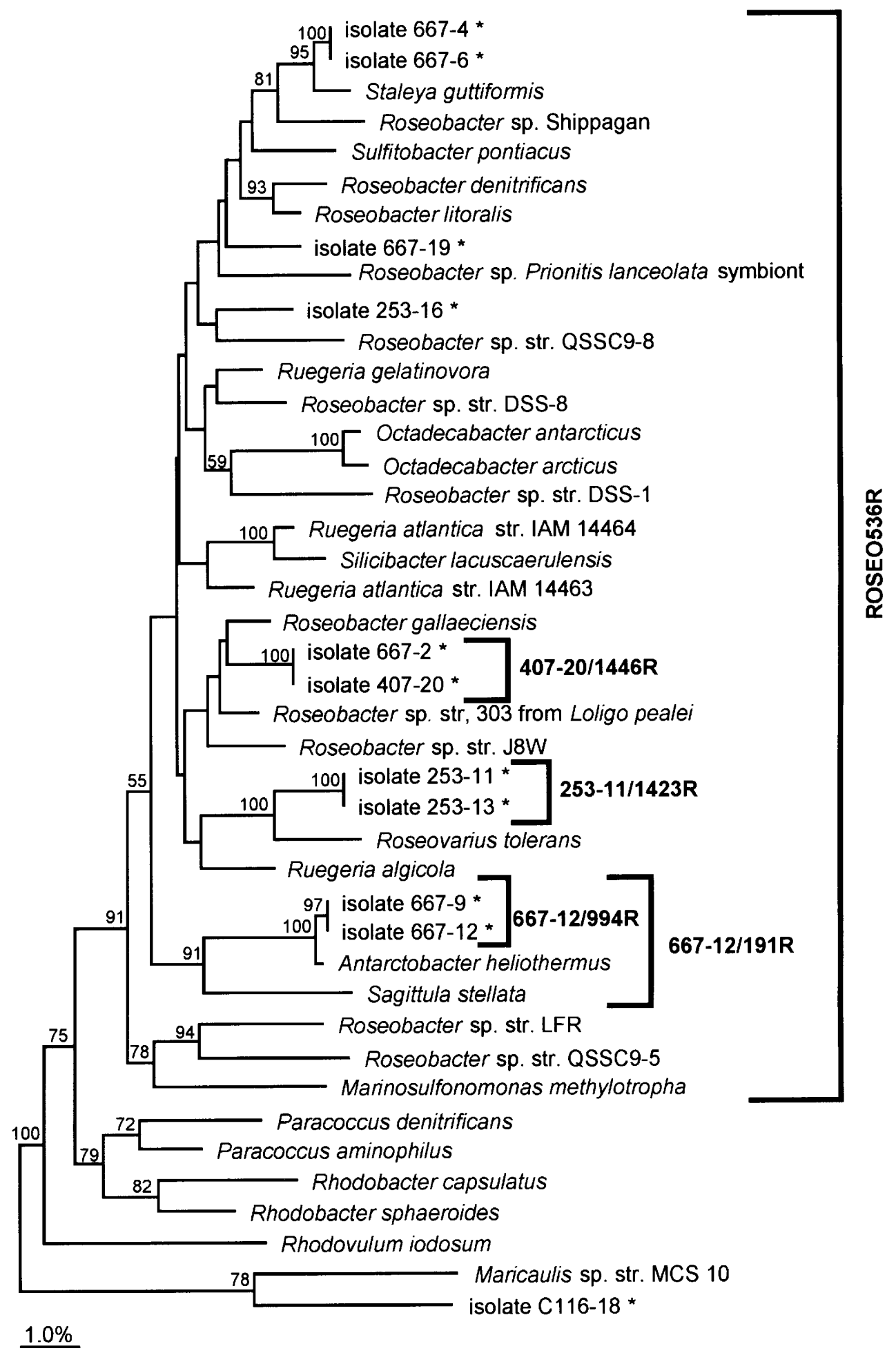

Fig. 1. Molecular phylogenetic tree inferred from I6S rRNA gene sequences representing the Roseobacter clade ( $\alpha$-Proteobacteria) using evolutionary distance methods. Asterisks indicate bacterial strains isolated from Alexandrium spp. by Gallacher et al. (unpublished). Numbers above nodes represent percentages $>50$ from 500 bootstrap repetitions from the neighbour joining analysis (Felsenstein, 1985), and oligonucleotide probes identified and developed in this study are indicated at brackets. Outgroups were pruned from the tree.

I-5 $\mathrm{h}$ to confirm that no annealing of probe to non-target rDNA had occurred. No quantification of signal intensity was made.

Clade probe ROSEO536R and taxon/cluster-specific probes 407-20/1446R, 667-12/191R, 667-12/994R and 253-11/1423R were tested against Roseobacter clade strains (clade neighbours) and non-target strains outside the clade containing five or fewer mismatches in their $16 \mathrm{~S}$
rRNA sequences (Figs 1, 3). Cluster-specific probe 66712/191R was not tested against Antarctobacter heliothermus or Sagittula stellata. The ratio of ROSEO536R to its competitor, ROSEOC 536R, was tested in a range of degreed intervals between $1: 5$ and $5: 1$, maintaining a constant concentration of 0.2 pmol. Optimal probe: competitor ratio was determined to be $1: 1$ and exhibited high specificity for all Roseobacter clade strains tested (Fig. 


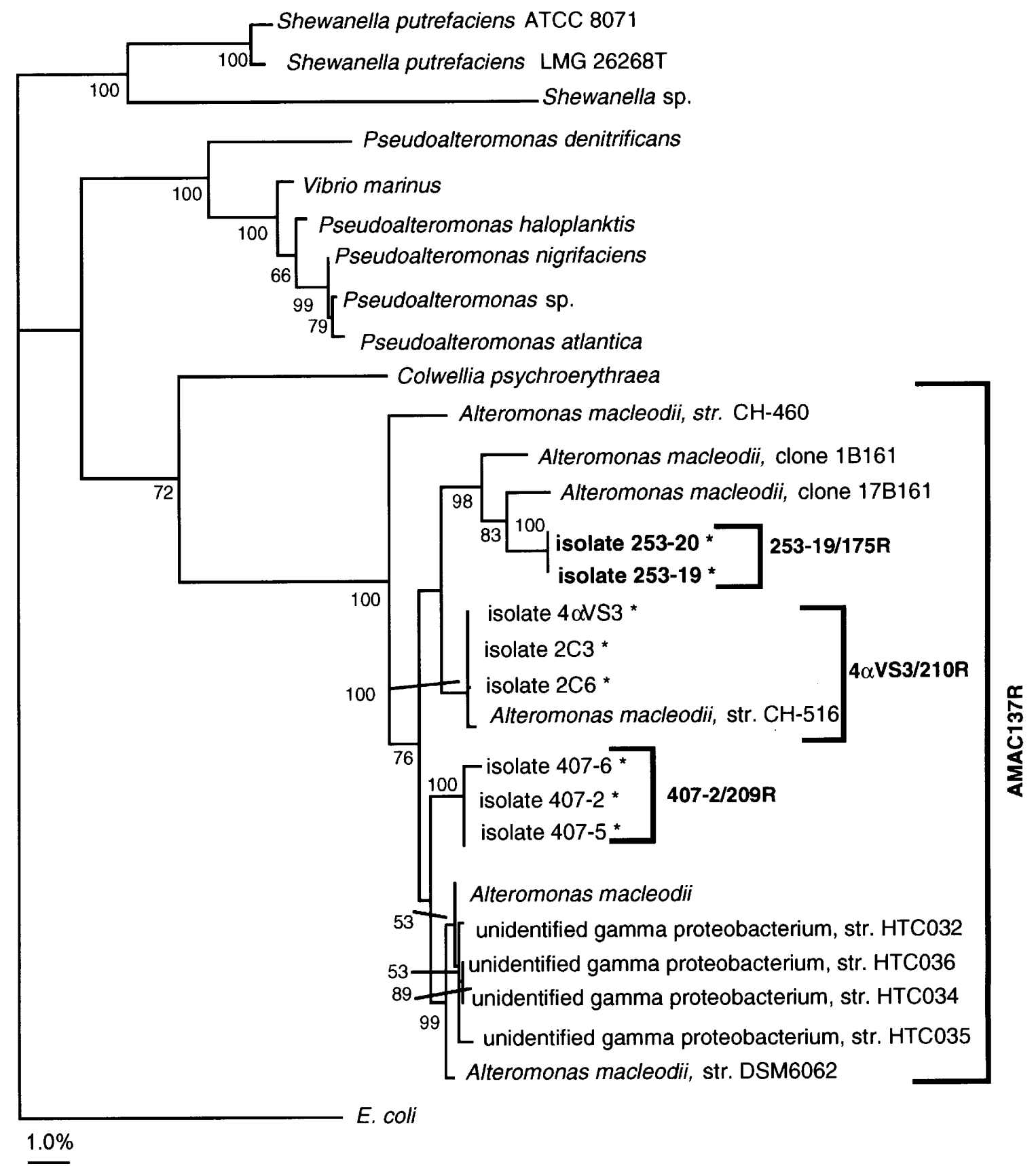

Fig. 2. Molecular phylogenetic tree inferred from I6S rRNA gene sequences representing the Alteromonas clade ( $\gamma$-Proteobacteria) using the maximum likelihood method. Asterisks indicate bacterial strains isolated from Alexandrium spp. by Gallacher et al. (unpublished). Numbers above nodes represent percentages $>50$ from 500 bootstrap repetitions from a neighbour joining analysis (Felsenstein, 1985), and oligonucleotide probes identified and developed in this study are indicated at brackets.

3, Column A). When tested against non-target strains containing one to three mismatches in their I6S rRNA sequences, stringent hybridization conditions of probe ROSEO536R were observed at $62{ }^{\circ} \mathrm{C}$. However, it was necessary to increase the hybridization temperature to $65{ }^{\circ} \mathrm{C}$ to remove non-specific signal that occurred with non-target strains containing four and five mismatches (data not shown). Taxon-specific probe 407-20/1446R was specific for its target strains, 407-20 and 667-2 (Fig. 1) and exhibited no non-specific signal with clade neighbours or a non-target strain, Paracoccus aminophilus, containing three mismatches (Fig. 3, column B). Cluster-specific probe 667-12/191R was specific for its target strains, $667-9$ and
667-12 (Fig. 1) and exhibited no non-specific signal with clade neighbours or non-target strain Paracoccus denitrificans with four mismatches (Fig. 3, column C). The signal from this probe was very weak due to the high hybridization stringency required for specificity (Table 1), which attenuated the signal. Probe 667-12/994R was specific for its target strains, 667-9 and 667-12 (Fig. 1) and exhibited no non-specific signal with clade neighbours or non-target strain Marinilabilia salmonicolor with two mismatches (Fig. 3, column D). Probe 253-11/1423R was specific for its target strains, 253-11 and 253-13 (Fig. 1) and exhibited no non-specific signal with clade neighbours containing three and four mismatches and non-target 


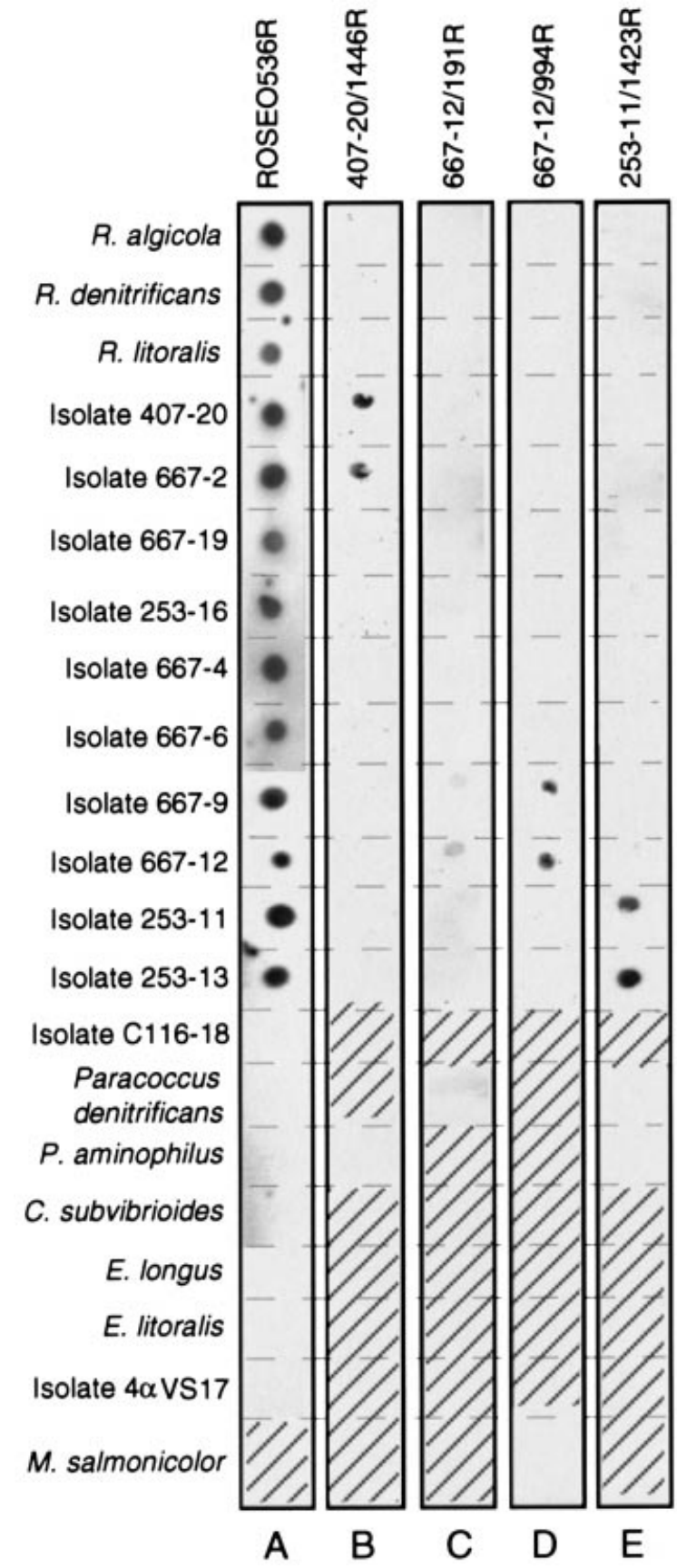

Fig. 3. Dot-blot hybridizations of PCR-amplified $16 \mathrm{~S}$ rRNA genes from members of the Roseobacter clade and non-target taxa with digoxygenin-labelled oligonucleotide probes: ROSEO536R, 407-20/1446R, 667-12/191R, 667-12/994R and 253-11/1423R. Hatched blocks indicate blanks.

strains Paracoccus denitrificans and P. aminophilus with two mismatches (Fig. 3, column E).

Similarly, clade probe AMAC137R and taxon-specific probes $407-2 / 209 \mathrm{R}, 4 \alpha \mathrm{VS} 3 / 210 \mathrm{R}$ and $253-19 / 175 \mathrm{R}$ were tested against Alteromonas clade strains (clade neighbours) and non-target strains outside of the clade containing five or fewer mismatches in their 16S rRNA sequences (Figs 2, 4). Probe AMAC137R was highly specific for its target strains (Fig. 2) and exhibited no nonspecific signal with non-target strains Pseudoalteromonas denitrificans and Shewanella baltica containing four and five mismatches, respectively (Fig. 4, column A). Taxon-

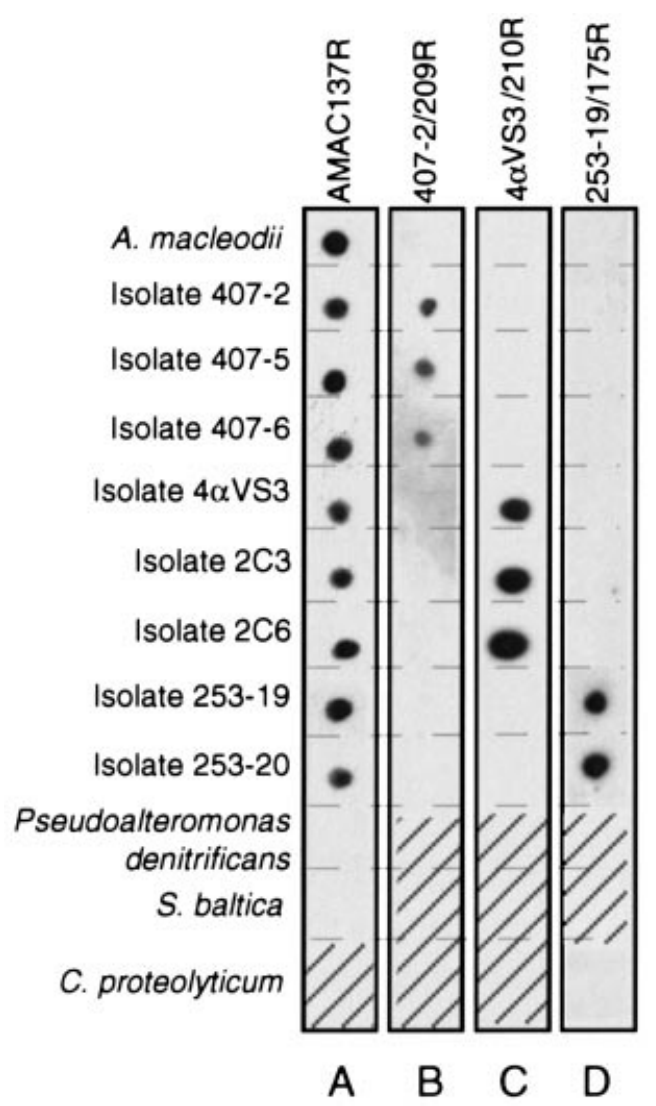

Fig. 4. Dot-blot hybridizations of PCR-amplified 16S rRNA genes from members of the Alteromonas clade and non-target taxa with digoxygenin-labelled oligonucleotide probes: AMAC137R, 407-2/209R, 4 $\alpha$ VS3/210R and 253-19/175R. Hatched blocks indicate blanks.

specific probe $407-2 / 209 \mathrm{R}$ was specific for its target strains, 407-2, 407-5 and 407-6 (Fig. 2); however, probe signal was weak due to high stringency conditions (Table 2, Fig. 4, column B). Loss of non-specific signal with clade neighbours was achieved at $65^{\circ} \mathrm{C}$ hybridization and by reducing the salt concentration in the second wash buffer (0.5a $\times$ SSC) (data not shown). Probe $4 \alpha V S 3 / 210 R$ was specific for its target strains, $4 \alpha \mathrm{VS} 3,2 \mathrm{C} 3$, Alteromonas macleodii str. $\mathrm{CH} 516$ and 2C6 (Fig. 2) and exhibited no non-specific signal with clade neighbours containing two and four mismatches (Fig. 4, column C). Probe 25319/175R was specific for its target strains, 253-19 and 253-20 (Fig. 2) and exhibited no non-specific signal with non-target strain $C$. proteolyticum containing four mismatches (Fig. 4, column D).

\section{Whole-cell in situ hybridization}

All hybridizations were performed at a uniform temperature. To maintain stringency and temperature hybridization uniformity, de-ionized formamide was added to the hybridization buffer to compensate for the required increase in hybridization temperature as determined by the $T_{\mathrm{d}}$ calculations used in the dot-blot experiments for each probe tested. After initial testing, several of the taxon-specific probes exhibited attenuation of fluorescent signal at the higher $(>10 \%)$ formamide 


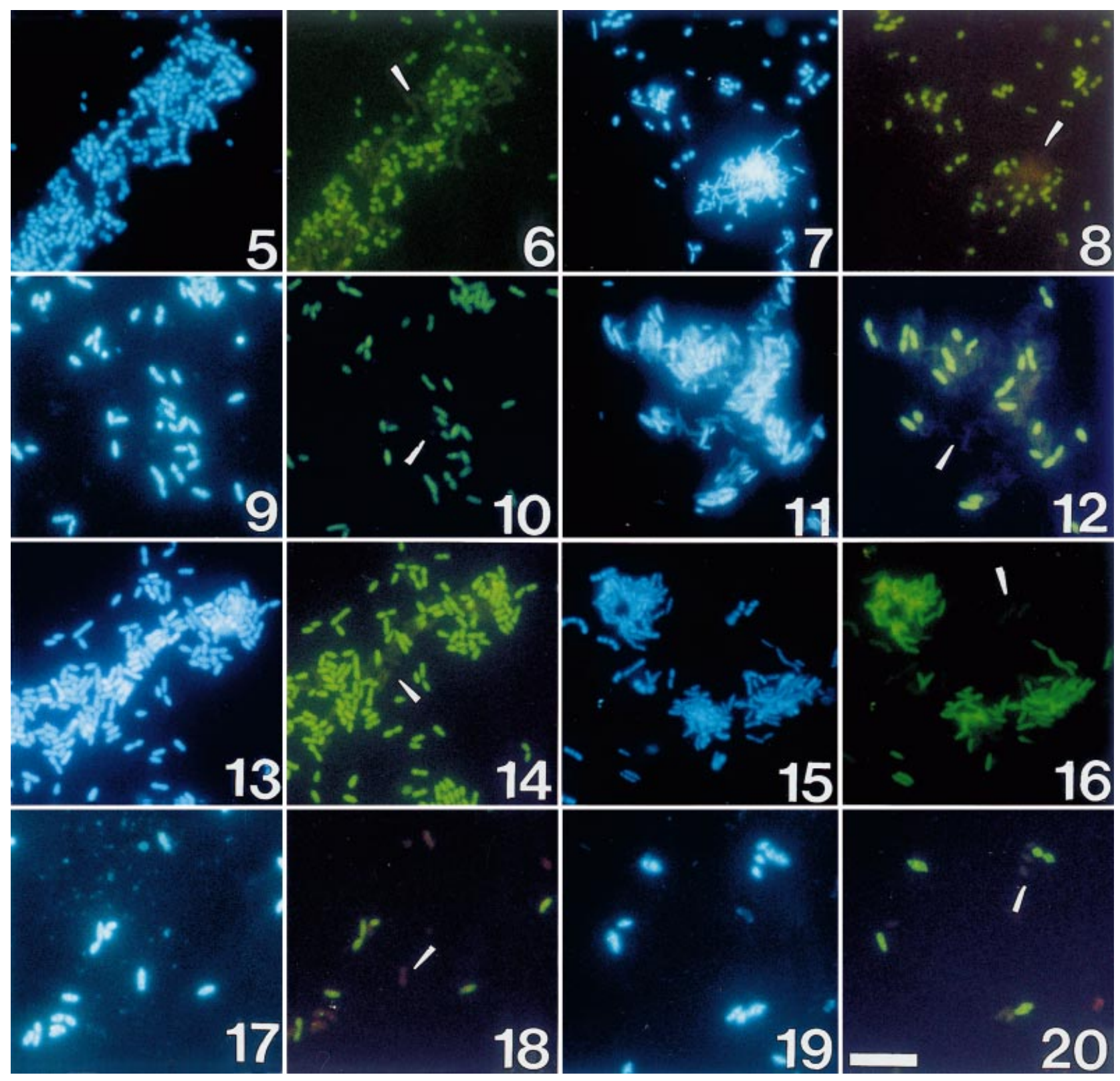

Figs 5-20. Whole-cell hybridization with fluorescein-labelled probes. Matched epifluorescence photosets, DAPI and probe-conferred fluorescein fluorescence from mixed bacterial cell preparations of target and non-target strains (indicated by arrowheads) are displayed for each field. Positive label of the fluorescein-labelled probe appears green. Figs 5, 6. Probe ROSEO536R hybridized with Roseobacter denitrificans and non-target Paracoccus denitrificans (one mismatch); Figs 7, 8. Probe ROSEO536R hybridized with R. denitrificans and nontarget E. longus (two mismatches); Figs 9, 10. Probe AMAC137R hybridized with A. macleodii and non-target Pseudoalteromonas denitrificans (four mismatches); Figs 11, 12. Probe AMAC137R hybridized with A. macleodii and non-target S. baltica (five mismatches); Figs 13, 14. Probe 407-20/1446R hybridized with isolate 407-20 and non-target P. aminophilus (three mismatches); Figs 15, 16. Probe 667-12/191R hybridized with isolate 667-12 and non-target Paracoccus denitrificans (four mismatches). Figs 17, 18. Probe 253-19/175R hybridized with isolate 253-19 and non-target isolate 2C3 ( $>$ five mismatches). Figs 19, 20. Probe 4 $\alpha$ VS3/210R hybridized with isolate $4 \alpha \mathrm{VS} 3$ and non-target isolate 407-2 (four mismatches). Scale bar represents: Fig. 20, $10 \mu \mathrm{m}$ and can be applied to all figures.

concentrations necessary to achieve optimal stringency at $46^{\circ} \mathrm{C}$. Based upon these results, dot-blot testing and $a$ priori estimates (Ramsing et al., 1993) of probe $T_{\mathrm{d}^{\prime}}$ it was decided to increase the uniform whole-cell in situ hybridization incubation temperature from the widely used $46{ }^{\circ} \mathrm{C}$ (Stahl \& Amann, 1991) to $50{ }^{\circ} \mathrm{C}$. Increase in the hybridization incubation temperature was not detrimental to the bacterial cell integrity or probe fluorescent signal (Stahl \& Amann, 1991). Optimal formamide concentration for probe specificity at a $50{ }^{\circ} \mathrm{C}$ hybridization temperature was determined by visualization of fluorescent signal brightness. Optimal formamide concentrations for probes are reported in Tables 1 and 2. All strains hybridized with the positive control probe EUB338 (CY3 label) and no signal was detected in hybridizations with the negative control probe NON338 (CY3 label) (data not shown). All other probes developed for this study were labelled with fluorescein.

Clade probe ROSE536R and taxon/cluster-specific probes $407-20 / 1446 R, 667-12 / 191 R, 667-12 / 994 R$ and 


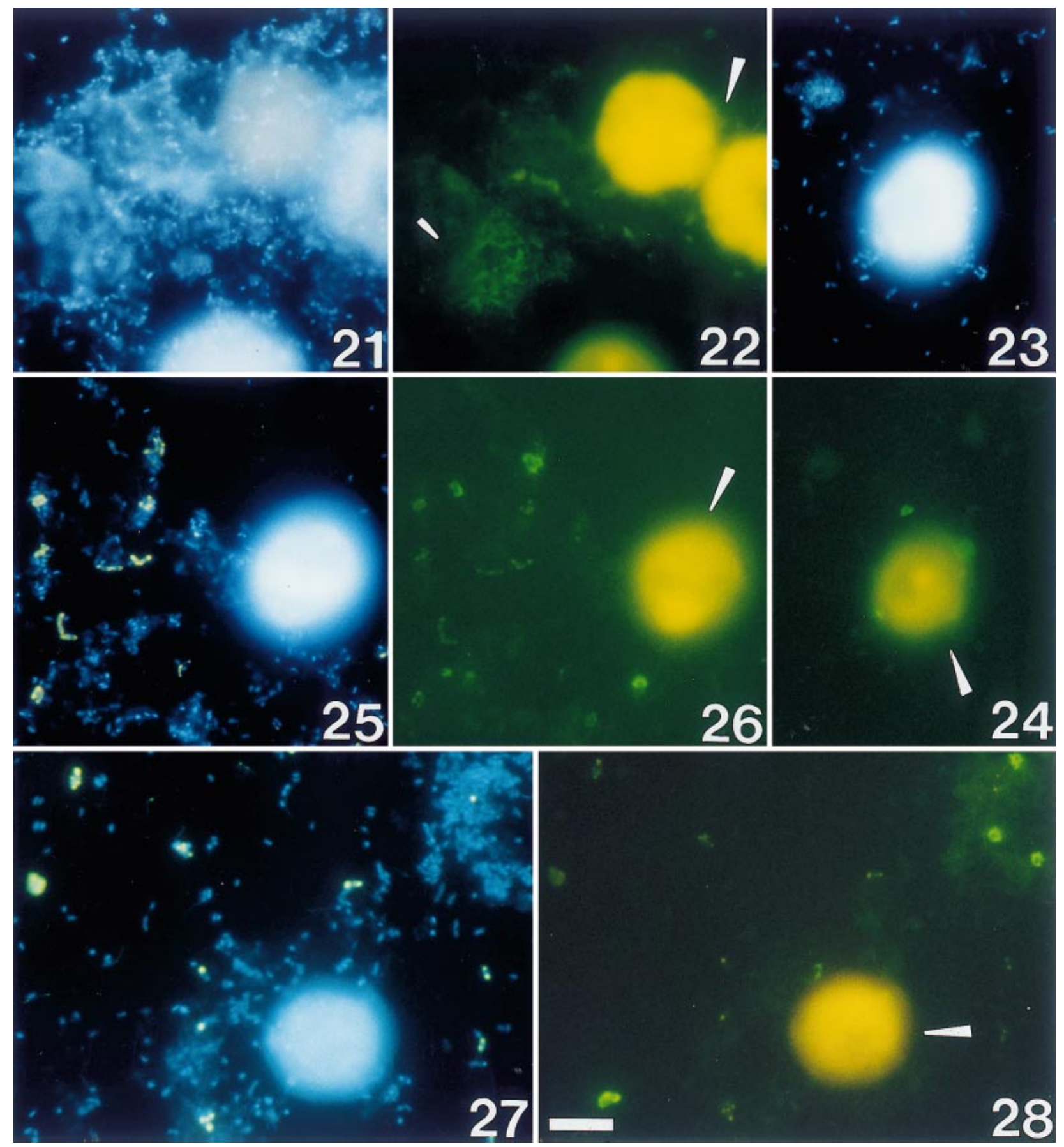

Figs 21-28. Whole-cell hybridization with fluorescein-labelled probes. Matched epifluorescence photosets of DAPI and probe-conferred fluorescein fluorescence from bacteria associated with Alexandrium spp. (indicated by large arrowheads) in culture are displayed for each field. Positive label of the fluorescein probe appears green and autofluorescence of dinoflagellate cells and some bacteria is yellow. Figs 21, 22 and 23, 24. Probe ROSEO536R hybridized with bacteria associated with toxic dinoflagellates $A$. tamarense (NEPCC407) and $A$. lusitanicum (NEPCC253), respectively. Note in Fig. 22 the mass of bacteria labelled with the ROSEO536R probe. Figs 25, 26 and $27,28$. Probe AMAC137R hybridized with bacteria associated with the toxic dinoflagellates A. tamarense (NEPCC407) and A. lusitanicum (NEPCC253), respectively. Scale bar represents: Fig. 28, $10 \mu \mathrm{m}$ and can be applied to all figures.

253-11/1423R were tested against Roseobacter clade strains (clade neighbours) and non-target strains outside the clade containing five or fewer mismatches in their $16 \mathrm{~S}$ rRNA sequences. Cluster-specific probe 667-12/191R was not tested against Antarctobacter heliothermus or Sagittula stellata. Similarly, clade probe AMAC137R and taxon-specific probes 407-2/209R, $4 \alpha \mathrm{VS} 3 / 210 \mathrm{R}$ and 25319/175R were tested against Alteromonas clade strains (clade neighbours) and non-target strains outside of the clade containing five or fewer mismatches in their $16 \mathrm{~S}$ rRNA sequences. Probe ROSEO536R demonstrated high specificity with isolates determined to be Roseobacter clade strains (Fig. I) (S. Gallacher, E. Mass, E. Moore \& G. Hold, unpublished data) and the available known target Roseobacter sp. strains, $R$. denitrificans, $R$. algicola and $R$. litoralis. No hybridization of ROSEO536R was detectable with non-target strains tested having one to five mismatches including C116-18 (this study), Paracoccus denitrificans, P. 
aminophilus, Caulobacter subvibrioides, Erythrobacter longus, Erythrobacter litoralis, $4 \alpha \mathrm{VS17}, 407-2$ and $4 \alpha \mathrm{VS} 3$ (this study). Hybridization of ROSEO536R with target $R$. denitrificans in mixed bacterial cell preparations with nontarget bacterial strains Paracoccus denitrificans (one mismatch) and E. longus (two mismatches) is demonstrated in Figs 5, 6 and 7, 8, respectively. The hybridization of ROSEO536R with other Roseobacter clade members and non-target strains is not shown. Probe AMAC137R was specific for isolates determined to be related to the genus Alteromonas (Fig. 2) (S. Gallacher, E. Mass, E. Moore \& G. Hold, unpublished data) and related to A. macleodii strain DSM6062. Non-target bacterial strains Pseudoalteromonas denitrificans and S. baltica, having four and five mismatches, respectively, to AMAC137R, exhibited no detectable hybridization to the probe (Figs 9, 10 and 11, 12, respectively). The hybridization of AMAC137R with other Alteromonas sp. clade members and non-target strains is not shown. Taxon/cluster-specific probes, 40720/1446R, 667-12/191R, 253-19/175R and 4aVS3/ 210R also demonstrated high specificity for target strains when tested with non-target strains in mixed bacterial cell preparations (Figs 13, 14; 15, 16; 17, 18; and 19, 20, respectively). No signal could be detected in hybridizations with probe 253-11/1423R, whereas probe 667-12/994R produced only a faint signal. In an attempt to remove possible protein blocking of target DNA, bacterial cell preparations were pre-treated with a $200 \mathrm{mM}$ $\mathrm{HCl}$ solution (Boehringer Mannheim, 1996) for up to 30 min but no enhancement of probe signal was observed (data not shown). We have subsequently found that by increasing the length of hybridization to overnight, we can achieve strong hybridization signals with both probes (Töbe et al., in press). The fluorescent signal of probe 407-2/209R was strong in target strains 407-2, 407-5 and 407-6, however, it exhibited a weak non-specific signal with non-target clade neighbours including $A$. macleodii (data not shown). The addition of formamide above a concentration of $10 \%$ in the HB resulted in dramatic attenuation of the target probe signal. The adjustment of $\mathrm{pH}$ and salt concentrations in the $\mathrm{HB}$ did not improve probe specificity (data not shown). Subsequent applications of this probe in overnight hybridizations have improved the specificity (Töbe et al., in press). The specificity of probes ROSEO536R and AMAC137R was also tested at an incubation temperature of $46^{\circ} \mathrm{C}$. A formamide concentration of $10 \%$ in the $\mathrm{HB}$ was sufficient to achieve target specificity for probe AMAC137R. A formamide concentration of $18 \%$ was optimal for probe ROSEO536R, whereas concentrations exceeding 20\% dramatically reduced the fluorescent signal.

As a test of potential probe application, the clade probes ROSE536R and AMAC137R were hybridized with samples from cultures of the toxic marine dinoflagellates Alexandrium tamarense (NEPCC407) and $A$. lusitanicum (NEPCC253). Figs 21, 22 and 23, 24 are hybridizations of fluorescein-labelled ROSEO536R with A. tamarense and A. lusitanicum cells, respectively. Figs. 25,
26 and 27, 28 are hybridizations of fluorescein-labelled AMAC137R with A. tamarense and A. lusitanicum cells, respectively. The green probe signal is easily distinguishable from autofluorescing bacteria and dinoflagellate cells (Figs 22, 24, 26 and 28, large arrowheads). It is evident from these experiments that bacteria belonging to these clades are maintained in these cultures and appear to be loosely associated with dinoflagellate cells.

\section{Discussion}

The clade- and species/cluster-specific probes developed in this study were designed to be used as a set, in either in situ or dot-blot hybridizations, to detect bacteria in toxic algal cultures and to examine bacterial/toxic algal interactions. $T_{\mathrm{d}}$ values for the probes ranged from 55 to $65^{\circ} \mathrm{C}$, which aids simultaneous probe application to samples. Testing of probes against non-target strains containing one to five mismatches (all available mismatch combinations) in their $16 \mathrm{~S}$ rRNA sequences provided a high level of confidence in probe specificity. Chemiluminescent and fluorescent signal of the clade probes, ROSEO536R and AMAC137R, was strong in both dot-blot and wholecell in situ hybridizations, indicating no probe selfcomplementation and that the target nucleic acids were easily accessible and not blocked by possible backfolding. The fluorescein label of the probes for in situ hybridization proved to be a good choice as the green probe-conferred signal was readily visualized and distinguishable from autofluorescing bacteria and dinoflagellate cells. Similarly, chemiluminescent and fluorescent signals of taxon-specific probes $407-20 / 1446 \mathrm{R}, 4 \alpha \mathrm{VS} 3 / 210 \mathrm{R}$ and $253-19 / 175 \mathrm{R}$ were strong in both dot-blot and whole-cell in situ hybridizations. Cluster-specific probe 667-12/191R proved to be suitable primarily for in situ hybridizations. Although 253-11/1423R and 407-2/209R were not functional as probes for whole-cell in situ hybridization in the conditions used here, they have been successfully used in field trials by changing the length of the hybridization to overnight and by changing the label to $\mathrm{CY} 3$ (Töbe et al., in press). The weak signal of probe 667-12/994R has been intensified by using a fluorescent label with a higher quantum yield, such as $\mathrm{CY}$ 3, making this probe functional for in situ hybridization (data not shown).

The clade probe AMAC137R matched 100\% to taxa inferred to be in the Alteromonas clade and the clade probe ROSEO536R matched $100 \%$ to most (95\%) of the taxa inferred to belong to the Roseobacter clade and one species outside the clade. Three of seven of the Roseobacter clade SSU rRNA genes that did not contain the target site for the Roseobacter clade-specific probe had substitutions of a single base that did not preserve the secondary structure of the SSU rRNA molecule, raising the possibility that these may be sequencing or PCR errors. In addition, the SSU rRNA gene for the gall symbiont of Prionitis lanceolata (Ashen \& Goff, 1996; U37762) possesses an unresolved base (N/G mismatch) in the region targeted by the ROSEO536R clade probe. This sequence has 
a ' $\mathrm{C}$ ' in the nucleotide position across the helix of this region of the SSU rRNA secondary structure, which provides a measure of evidence that this sequence does in fact contain the probe target site. The SSU rRNA for Sulfitobacter pontiacus (Sorokin, 1995; Y13155) contains a single base pair substitution that results in a non-canonical base pair but does not possess a reciprocal substitution across the helix of this region of the SSU rRNA secondary structure. All other available Sulfitobacter spp. SSU rRNA sequences do not have this substitution but instead possess the probe target site exactly. The ROSEO536R probe also showed 100\% similarity to the 16S rRNA sequence of Rhodovulum iodosum (Straub et al., 1999), which is not associated with the Roseobacter clade. Ideally, hybridization of these microorganisms with the probe would confirm whether or not the target sequence is present. Although the clade probe ROSEO536R could not be tested on all members of its clade target, our analyses using the Roseobacter clade isolates from Alexandrium spp. (S. Gallacher, E. Mass, E. Moore \& G. Hold, unpublished data), cultures obtained from the DSMZ and several isolated strains of Octadecabacter articus and Octadecabacter antarcticus (R. Brinkmeyer, K. Ravenschalg, R. I. Amann \& E. Helmke, unpublished data) indicated that our probe is highly specific. Hybridization testing of AMAC137R with Alteromonas spp. isolates from Gallacher et al. (unpublished data) and A. macleodii also indicated high target specificity of this probe.

The Roseobacter clade, inferred by our phylogenetic analyses and recently referred to as the 'Roseobacter group' by González et al. (1999), encompasses a physiologically and geographically diverse group of bacteria within the $\alpha$-subclass of the Proteobacteria. These heterotrophic bacteria are proving to be important in biogeochemical processes such as a DMSP degradation (Ledyard et al., 1993; González et al., 1999), lignin transformation (González et al., 1997) and methyl and inorganic sulphur compound utilization (Sorokin et al., 1995; Holmes et al., 1997; González et al., 1999; Pukall et al., 1999a). Bacteria of this clade have been discovered in a wide range of marine habitats including coasts (González \& Moran, 1997; Rappé et al., 1997; Giuliano et al., 1999), sediments (Sobecky et al., 1998), snow aggregates (Rath et al., 1998) and as endosymbionts or in association with macroalgae (Ashen \& Goff, 1996; Shiba, 1991) and invertebrates (Barbieri et al., 1996; Ruiz-Ponte et al., 1998). Octadecabacter antarcticus and O. arcticus (Gosink et al., 1997) isolated from polar sea ice, Antarctobacter heliothermus (Labrenz et al., 1998) and Roseovarius tolerans (Labrenz et al., 1999) isolated from a hypersaline lake in Antarctica and Silicibacter lacuscaerulensis (Petursdottir \& Kristjansson, 1997) isolated from a geothermal lake in Iceland represent members of this clade found in extreme environments.

The significance of the Roseobacter clade in marine biogeochemical processes was first recognized by González \& Moran (1997) and González et al. (1999). They used oligonucleotide probes specific for a portion of the $\alpha$-subclass of the Proteobacteria to identify bacteria in the Roseobacter clade that could metabolize dimethyl sulphoniopropionate (DMSP) and other sulphur compounds. However, these probes only partially targeted the Roseobacter clade and also did not target a DMSPdegrading Roseobacter clade bacterium that had been earlier described by Ledyard et al. (1993). Our ROSEO536R clade probe targets the entire clade and would be a more useful probe to identify Roseobacter clade bacteria in environmental samples and in studies of endosymbiosis. Roseobacter clade bacteria have also been isolated from cultures of toxic dinoflagellates (Gallacher et al., unpubl.; Hold et al., submitted; Lafay et al., 1995). Provic et al. (1998) found a predominance of Roseobacter spp. bacteria in cultures of the toxic dinoflagellate, Prorocentrum lima. Autonomous toxigenesis has been observed in Roseobacter clade bacteria that were isolated by Gallacher et al. (unpublished data) from cultures of toxic Alexandrium spp. These include bacterial strains 253-11 and 253-13. The taxon-specific probe 253-11/1423R was designed to target these toxigenic bacteria. Other probes targeting non-toxigenic isolates of the Roseobacter clade, together with the ROSEO536R clade probe, can also provide much-needed answers to questions of bacterial/ toxic algal dynamics.

The Alteromonas clade of the $\gamma$-subclass Proteobacteria includes Alteromonas macleodii, for which the clade was named, bacteria isolated from Alexandrium spp. (S. Gallacher, E. Mass, E. Moore, \& G. Hold, unpublished data), unidentified $\gamma$-Proteobacteria isolated from deepsea sites off the southern coast of Japan (Takami et al., 1998) and uncultured $\gamma$-Proteobacteria sampled in the Mediterranean Sea (Acinas et al., 1999; Pukall et al., 1999b). The Alteromonas-Pseudomonas-Vibrio group is often found in association with toxic dinoflagellates in culture and dinoflagellate blooms and many strains have been documented as toxigenic (Buck \& Pierce, 1989; Tosteson et al., 1989; Doucette \& Trick, 1995; Gallacher \& Birkbeck, 1993, 1995; Onji et al., 1995; Doucette \&

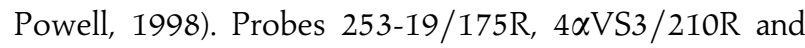
407-2/209R are specific for toxigenic bacteria within the Alteromonas clade. These bacteria have been observed to excrete $1 \times 10^{-4} \mathrm{fmol}$ of toxin (saxitoxin or STX equivalents per cell) (Gallacher et al., 1997). Localization of these bacteria within or on algal cells of the Alexandrium spp. cultures from which they were isolated may explain their function in this interaction. Whether these bacteria are associated with Alexandrium spp. and other toxic dinoflagellates during bloom events is an interesting question. Our Alteromonas clade probe, AMAC137R, and the taxon-specific probes targeting members of this clade should reveal more information regarding the distribution of these bacteria and their possible role in toxigenesis.

Preliminary testing of the probes ROSEO536R and AMAC137R on samples from Alexandrium spp. cultures indicated that bacteria affiliated with the Roseobacter and Alteromonas clades were present and easily observable. The clade- and species/cluster-specific probes designed in 
this study can be applied to other cultures of toxic algae to determine whether Roseobacter spp. and Alteromonas spp. are persistent in the bacterial flora. In addition, these probes could be used to further examine succession of bacterial community structure during the course of HABs. The application of our taxon/cluster-specific probes could further define community structure by detecting the presence or absence of potential toxigenic and nontoxigenic bacteria. However, we must emphasize that detection of bacteria with our taxon-specific probes designed for toxigenic bacteria is not reliable proof of toxigenesis. The genes responsible for toxin production are probably not associated with the 16S rRNA and the ecology of toxin production is relatively unexplored. Additionally, the specificity of oligonucleotide probes is based upon 16S rRNA sequences available during the design process. New $16 \mathrm{~S}$ rRNA sequences are introduced into the GenBank database on a regular basis and the specificity of our taxon-specific probes must be continually reaffirmed. The probes ROSEO536R and AMAC137R, first designed in the spring of 1997, remain specific for the Roseobacter and Alteromonas clades, respectively. The application of our probes to screen samples taken during the 1999 PSP monitoring season in the Orkney Islands is presented in Töbe et al. (in press). Localization of toxigenic and non-toxigenic bacteria on or within cells of Alexandrium spp. will be the next step in utilizing the clade- and taxon/cluster-specific probes to provide insights into bacterial/toxic algal interactions.

\section{Acknowledgements}

The technical assistance of Ms U. Wellbrock and useful discussions with $\mathrm{Dr}$ R. Amann are gratefully acknowledged. This research was funded from the EU FAIR CT96-1558.

\section{References}

Acinas, S.G., Anton, J. \& Rodriguez-Valera, F. (1999). Diversity of freeliving and attached bacteria in offshore western Mediterranean waters as depicted by analysis of genes encoding $16 \mathrm{~S}$ rRNA. Appl. Environ. Microbiol., 65 : 514-522.

Alm, E.W., Oerther, D.B., Larsen, N., Stahl, D.A. \& Raskin, L. (1996). The oligonucleotide probe database. Appl. Environ. Microbiol., 62 : 3557-3559.

Altschul, S.F., Gish, W., Miller, W., Myers, E.W. \& Lipman, D.J. (1990). Basic local alignment search tool. J. Mol. Biol., 215 : 403-410.

Amann, R.I., Krumholz, L. \& Stahl, D.A. (1990). Fluorescent-oligonucleotide probing of whole cells for determinative, phylogenetic and environmental studies in microbiology. J. Bacteriol., 172 : 762-770.

Amann, R.I., Zarda, B., StAhl, D.A. \& Schleifer, K.-H. (1992). Identification of individual prokaryotic cells by using enzyme-labelled, rRNA-targeted oligonucleotide probes. Appl. Environ. Microbiol., 58 : 3007-3011.

Ashen, J.B. \& Goff, L.J. (1996). Molecular identification of a bacterium associated with gall formation in the marine red alga Prionitis lanceolata. J. Phycol., 32 : 286-297.

Babinchak, J.A., McGovern, E.R. \& Doucette, G.J. (1998). Isolation and characterization of the bacterial flora associated with PSP-related dinoflagellate species. In Harmful Algae (Reguera, B., Blanco, J., Fernández, M.L. \& Wyatt, T., editors), 410-413. Xunta de Galicia and Inter- governmental Oceanographic Commission of UNESCO, Santiago de Compostela, Spain.

Barbieri, E., Gulledge, J., Moser, D. \& Chien, C.-C. (1996). New evidence for bacterial diversity in the accessory nidamental gland of the squid (Loligo pealei). Biol. Bull., 191 : 316-317.

Bates, S.S., Douglas, D.J., Doucette, G.J. \& Leger, C. (1995). Enhancement of domoic acid production by reintroducing bacteria to axenic cultures of the diatom Pseudonitzschia multiseries. Nat. Toxins, 3: 428-435.

Benson, D.A., Boguski, M.S., Lipman, D.J., Ostell, J., Oullette, B.F., Rapp, B.A. \& Wheeler, D.L. (1999). GenBank. Nucleic Acids Res., 27: 1-7.

Boehringer MANnheim (1996). Nonradioactive in situ hybridization application manual. Boehringer Mannheim, Biochemica. Mannheim, Germany.

Bruns, A. \& Berthe-Corte, L. (1998). In situ detection of bacteria in continuous-flow cultures of seawater sediment suspensions with fluorescently labelled rRNA-directed oligonucleotide probes. Microbiology, 144: 2783-2790.

BuCK, J.D. \& Pierce, R.H. (1989). Bacteriological aspects of Florida red tides: a revisit and newer observations. Estuar. Coastal Shelf Sci., 29: 317-326.

DeLong, E.F., Wickham, G.S. \& Pace, N.R. (1989). Phylogenetic stains: ribosomal RNA-based probes for the identification of single microbial cells. Science, 243 : 1360-1363.

Doucette, G.J. (1995). Interactions between bacteria and harmful algae: a review. Nat. Toxins, 3: 65-74.

Doucette, G.J. \& Powell, C.L. (1998). Algal-bacterial interactions: can they determine the PSP-related toxicity of dinoflagellates? In Harmful Algae (Reguera, B., Blanco, J., Fernández, M.L. \& Wyatt T., editors), 406-409. Xunta de Galicia and Intergovernmental Oceanographic Commission of UNESCO, Santiago de Compostela, Spain.

DoucetTe, G.J. \& TRICK, C.G. (1995). Characterization of bacteria associated with different isolates of Alexandrium tamarense. In Harmful Marine Algal Blooms (Lassus, P., Arzul, G., Erad-LeDenn, E., Gentien, P. \& Marcaillou, C., editors), 33-37. Lavoisier, Paris.

Doucette, G.J., Kodama, M., Franca, S. \& Gallacher, S. (1998). Bacterial interactions with harmful algal bloom species: bloom ecology, toxigenesis and cytology. In Physiological Ecology of Harmful Algal Blooms (Anderson, D.M., Cembella, A.D. \& Hallegraeff, G.M., editors), 619-647. NATO ASI series, vol. G 41. Springer, Berlin.

Doyle, J.J. \& Doyle, J.L. (1990). Isolation of plant DNA from fresh tissue. Focus, 12: 13-15.

Edwards, U., Rogall, T., Blöcker, H., Emde, M. \& Böttger, E.C. (1989). Isolation and direct complete nucleotide determination of entire genes: characterization of gene coding for $16 \mathrm{~S}$ ribosomal RNA. Nucleic Acids Res., 17: 7843-7853.

Felsenstein, J. (1985). Confidence limits on phylogenies: an approach using the bootstrap. Evolution, 39: 783-791.

Felsenstein, J. (1993). PHYLIP manual, version 3·5. Department of Genetics, University of Washington, Seattle, Washington.

Fitch, W.M. \& Margoliash, E. (1967). Construction of phylogenetic trees a method based on mutation distances as estimated from cytochrome c sequences is of general applicability. Science, 155: 279-284.

Franca, S., Pinto, L., Alvito, P., Sousa, I., Vasconcelos, V. \& Doucette, G.J. (1996). Studies on prokaryotes associated with PSP producing dinoflagellates. In Harmful and Toxic Algal Blooms (Yasumoto, T., Oshima, Y. \& Fukuyo, Y., editors), 347-350. Intergovernmental Oceanographic Commission of UNESCO.

Fukami, K., Yuzawa, A., Nishijima, T. \& Hata, Y. (1991a). Isolation and properties of a bacterium inhibiting the growth of Gymnodinium nagasakiense. Nippon Suisan Gakkaishi, 58: 1073-1077.

Fukami, K., Nishijima, T., Murata, H., Doi, S. \& Hata, Y. (1991b). Distribution of bacteria influential on the development and the decay of Gymnodinium nagasakiense red tide and their effects on algal growth. Nippon Suisan Gakkaishi, 57: 2321-2326.

Gallacher, S. \& BirkBeCK, T.H. (1993). Effect of phosphate concentration on production of tetrodotoxin by Alteromonas tetraodonis. Appl. Environ. Microbiol., 59: 3981-3983.

GALLACHER, S. \& BIRKBECK, T.H. (1995). Isolation of marine bacteria producing sodium channel blocking toxins and the seasonal variation in their frequency in seawater. In Harmful Marine Algal Blooms (Lassus, P., Arzul, G., Erad-LeDenn, E., Gentien, P. \& Marcaillou-LeBaut, C., editors), 445-450. Lavoisier, Paris. 
Gallacher, S., Flynn, K.J., Leftley, J., Lewis, J., Munro, P.D. \& Birkbeck, T.H. (1996). Bacterial production of sodium channel blocking toxins. In Harmful and Toxic Algal Blooms (Yasumoto, T., Oshima, Y. \& Fukuyo, Y., editors), 355-358. Intergovernmental Oceanographic Commission of UNESCO.

Gallacher, S., Flynn, K.J., Franco, J.M., Brueggemann, E. \& Hines, G.B. (1997). Evidence for the production of paralytic shellfish toxins by bacteria associated with Alexandrium spp. (Dinophyta) in culture. Appl. Environ. Microbiol., 63 : 239-245.

Giovannoni, S.J., Delong, E.F., Olsen, G.J. \& Pace, N.R. (1988). Phylogenetic group-specific oligodeoxynucleotide probes for identification of single microbial cells. J. Bacteriol., 170: 720-726.

Giuliano, L., DeDomenico, M., DeDomenico, E., Hoefle, M. \& Yakimov, M.M. (1999). Identification of culturable oligotrophic bacteria within naturally occurring bacterioplankton communities of the Ligurian Sea by I6S rRNA sequencing and probing. Microb. Ecol., 37: 77-85.

Glöckner, F.O., Amann, R., Alfreider, A., Pernthaler, J., Psenner, R., Trebesius, K.H. \& Schleifer, K.-H. (1996). An in situ hybridization protocol for detection and identification of planktonic bacteria. Syst. Appl. Microbiol., 19: 403-406.

GONZÁLEZ, J.M. \& MorAN, M.A. (1997). Numerical dominance of a group of marine bacteria in the $\alpha$-subclass of the class Proteobacteria in coastal seawater. Appl. Environ. Microbiol., 63: 4237-4242.

GonzÁlez, C., Tosteson, G., Hensley, V. \& Tosteson, T.R. (1995). Associated bacteria and toxicity development in cultured Ostreopsis lenticularis. In Harmful Marine Algal Blooms (Lassus, P., Arzul, G., EradLeDenn, E., Gentien, P. \& Marcaillou-LeBaut, C., editors), 451-456. Lavoisier, Paris.

GonzÁlez, J.M., Mayer, F., Moran, M.A., Hodson, R.E. \& Whitman, W.B. (1997). Sagittula stellata gen. nov., sp. nov., a lignin-transforming bacterium from a coastal environment. Int. J. Syst. Bacteriol., 47: 773-780.

GonzÁlez, J.M., Kiene, R.P. \& Moran, M.A. (1999). Transformation of sulphur compounds by an abundant lineage of marine bacteria in the $\alpha$ subclass of the class Proteobacteria. Appl. Environ. Microbiol., 65 : 3810-3819.

Gosink, J.J., Herwig, R.P. \& Staley, J.T. (1997). Octadecabacter arcticus gen. nov., sp. nov. and $O$. antarcticus, sp. nov., nonpigmented, psychrophilic gas vacuolate bacteria from polar sea ice and water. Syst. Appl. Microbiol., 20: $356-365$

Haygood, M.G. \& NeALSON, K.H. (1985). Mechanisms of ion regulation of luminescence in Vibrio fischeri. J. Bacteriol., 162: 209-216.

Holmes, A.J., Kelly, D.P., BaKer, S.C., Thompson, A.S., De Marco, P., Kenna, E.M. \& Murrell, J.C. (1997). Methylosulfonomonas methylovora gen. nov., sp. nov. and Marinosulfonomas methylotropha gen. nov., sp. nov.: novel methylotrophs able to grow on methanesulfonic acid. Arch. Microbiol., 167: 46-53.

IshidA, Y., YoshinagA, I., KIM, M.-C. \& UchidA, A. (1997). Possibility of bacterial control of harmful blooms. In Progress in Marine Ecology (Martius, M.T., Sato, M.I.Z., Tiedje, J.M., Hagler, L.C.N., Dobereiner, J. \& Sanchez, P.S., editors), 495-500. Proceedings of the Seventh International Symposium on Microbial Ecology. Brazilian Society for Microbiology, Santos, Brazil.

Kimura M. (1980). A simple method for estimating evolutionary rates of base substitutions through comparative studies of nucleotide sequences. J. Mol. Evol., 16: 111-120.

Kodama, M., Ogata, T. \& Sato, S. (1988). Bacterial production of saxitoxin. Agric. Biol. Chem., 52 : 1075-1077.

Kodama, M., Ogata, T., Sakamoto, S., Sato, S., Honda, T. \& Minantani, T. (1990). Production of paralytic shellfish toxins by a bacterium Moraxella sp. isolated from Protogonyaulax tamarensis. Toxicon, 28: 707-714.

Kopp, M., Doucette, G.J., Kodama, M., Gerdts, G., Schütt, C. \& Medlin, L.K. (1997). Phylogenetic analysis of selected toxic and non-toxic bacterial strains isolated from the toxic dinoflagellate Alexandrium tamarense. FEMS Microbiol. Ecol., 24 : 251-257.

Labrenz, M., Collins, M.D., Lawson, P.A., Tindall, B.J., Braker, G. \& Hirsch, P. (1998). Antarctobacter heliothermus gen. nov., sp. nov., a budding bacterium from hypersaline and heliothermal Ekho Lake. Int. J. Syst. Bacteriol., 48: 1363-1372.

Labrenz, M., Collins, M.D., Lawson, P.A., Tindall, B.J., Schumann, P. \& Hirsch, P. (1999). Roseovarius tolerans gen. nov., sp. nov., a budding bacterium with variable bacteriochlorophyll a production from hypersaline Ekho Lake. Int. J. Syst. Bacteriol., 49: 137-147.
Lafay, B., Ruimy, R., Rausch de Traubenberg, C., Breittmayer, V., Gauthier, M.J. \& CHRISTEN, R. (1995). Roseobacter algicola sp. nov., a new marine bacterium isolated from the phycosphere of the toxin-producing dinoflagellate Prorocentrum lima. Int. J. Syst. Bacteriol., 45 : 290-296.

Larsen, N., Olssen, G.J., Maidak, B.L., McCaughey, M.J., Overbeek, R., Macke, R., Marsch, T.L. \& Woese, C.R. (1993). The ribosomal database project. Nucleic Acids Res., 21 : 3021-3023.

LATHE, R. (1985). Synthetic oligonucleotide probes deduced from amino acid sequences data. Theoretical and practical considerations. J. Mol. Biol., 183 : $1-12$.

Ledyard, K.M., Delong, E.F. \& DACEY, J.W.H. (1993). Characterization of a DMSP-degrading bacterial isolate from the Sargasso Sea. Arch. Microbiol., 160: $312-318$.

MaAs, E.W., van Gennip, E., Truman, P. \& Brooks, H.J.L. (1998). The effect of growth conditions on the production of sodium channel blockers by two marine bacterial isolates from toxic algal cultures. In Harmful Algae (Reguera, B., Blanco, J., Fernández, M.L. \& Wyatt T., editors), 414-416. Xunta de Galicia and Intergovernmental Oceanographic Commission of UNESCO, Santiago de Compostela, Spain.

Maidak, B.L., Cole, J.R., Parker, C.T. Jr, Garrity, G.M., Larsen, N., Li, B., Lilburn, T.G., McCaughey, M.J., Olsen, G.J., Overbeek, R., Pramanik, S., Schmidt, T.M., Tiedje, J.M. \& Woese, C.R. (1999). A new version of the RDP (Ribosomal Database Project). Nucleic Acids Res., 27: 171-173.

Manz, W., Amann, R., Ludwig, W., Wagner, M. \& Schleifer, K.-H. (1992). Phylogenetic oligodeoxynucleotide probes for the major subclasses of proteobacteria: problems and solutions. Syst. Appl. Microbiol., 15 : 593-600.

Ogata, T., Kodama, M., Komaru, K., Sakamoto, S., Sato, S. \& Simidu, U. (1990). Production of paralytic shellfish toxins by bacteria isolated from toxic dinoflagellates. In Toxic Marine Phytoplankton (Granéli, E., Sundstrom, B., Edler, L. \& Anderson, D.M., editors), 311-315. Elsevier, Amsterdam.

Olsen, G.H. (1988). Phylogenetic analysis using ribosomal RNA. Methods Enzymol., 164: 793-812.

OnjI, M., Sawabe, T. \& Ezura, Y. (1995). Effect of marine bacteria isolated from Tanabe Bay on the growth of marine red tide dinoflagellate, Gymnodinium mikimotoi. Bull. Fac. Fish. Hokkaido Univ., 46: 39-46.

Pernthaler, J., Glöckner, F.O., Unterholzner, S., Alfreider, A., Psenner, R. \& AMANN, R. (1998). Seasonal community and population dynamics of pelagic Bacteria and Archaea in a high mountain lake. Appl. Environ. Microbiol., 64 : 4299-4306.

Petursdottir, S.K. \& Kristjansson, J.K. (1997). Silicibacter lacuscaerulensis gen. nov., sp. nov., a mesophilic moderately halophilic bacterium characteristic of the Blue Lagoon geothermal lake in Iceland. Extremophiles, 1: 94-99.

Provic, I., Brümmer, F., Brigge, T., Görtz, H.G., Gerdts, G., Schütt, C., ElbrÄChter, M. \& MÜlleR, W.E.G. (1998). Bacteria of the genus Roseobacter associated with the toxic dinoflagellate Prorocentrum lima. Protista, 149 : 347-357.

Pukall, R., Buntefuss, D., Frühling, A., Rohde, M., Kroppenstedt, R.M., Burghardt, J., Lebaron, P., Bernard, L. \& Stackebrandt, E. (1999a). Sulfitobacter mediterraneus sp. nov., a new sulfite-oxidizing member of the alpha-Proteobacteria. Int. J. Syst. Bacteriol., 49: 513-519.

Pukall, R., Paeuker, O., Buntefuss, D., Ulrichs, G., Lebaron, P., Bernard, L., Guindulain, T., Vives-Rego, J. \& Stackebrandt, E. (1999b). High sequence diversity of Alteromonas macleodii-related cloned and cellular $16 \mathrm{~S}$ rDNAs from a Mediterranean seawater mesocosm. FEMS Microbiol. Ecol., 28 : $335-344$.

Ramsing, N.B., KüHL, M. \& JøRgensen, B.B. (1993). Distribution of sulfatereducing bacteria, $\mathrm{O}_{2}$, and $\mathrm{H}_{2} \mathrm{~S}$ in photosynthetic biofilms determined by oligonucleotide probes and microelectrodes. Appl. Environ. Microbiol., 59: 3840-3849.

Ramsing, N.B., Fossing, H., Ferdelman, T.T., Andersen, F. \& Thamdrup, B. (1996). Distribution of bacterial populations in a stratified fjord (Mariager Fjord, Denmark) quantified by in situ hybridization and related to chemical gradients in the water column. Appl. Environ. Microbiol., 62 : 1391-1404.

RappÉ, M.S., KeMP, P.F. \& GiovanNONI, S.J. (1997). Phylogenetic diversity of marine coastal picoplankton 16S rRNA genes cloned from the continental shelf off Cape Hatteras, North Carolina. Limnol. Oceanogr., 42 : 811-826.

Rath, J., Wu, K.Y., Herndl, G.J. \& DeLong, E.F. (1998). High phylogenetic diversity in a marine snow-associated bacterial assemblage. Aquat. Microb. Ecol., 14: 261-269. 
Rausch de Traubenberg, C. \& Lassus, P. (1991). Dinoflagellate toxicity: are marine bacteria involved? Evidence from the literature. Marine Microb. Food Webs, 5 : 205-226.

Romalde, J.L., BarjA, J.L. \& Toranzo, A.E. (1990). Vibrios associated with red tides caused by Mesodinium rubrum. Appl. Environ. Microbiol., 56: 3615-3619.

Ruiz-Ponte, C., Cilia, V., Lambert, C. \& Nicolas, J.L. (1998). Roseobacter gallaeciensis sp. nov., a new marine bacterium isolated from rearings and collectors of the scallop Pecten maximum. Int. J. Syst. Bacteriol., 48: 537-542.

Saiki, R.K., Gefland, D.H., Stoffel, S., Scharf, S.J., Higuchi, R., Horn, G.T., Mullis, G.T. \& Erlich, H.A. (1988). Primer-directed enzymatic amplification of DNA with a thermostable DNA polymerase. Science, 239 : 487-491.

SHIBA, T. (1991). Roseobacter litoralis gen. nov., sp. nov. and Roseobacter denitrificans sp. nov., aerobic pink-pigmented bacteria, which contain bacteriochlorophyll a. Syst. Appl. Microbiol., 14: 140-145.

SiLvA, M. (1962). Some observation on marine dinoflagellate cultures. III. Gonyaulax spinifera (Clap. and Lach.) Dies., Gonyaulax tamarensis Leb., and Peeridinium trochoideum (Stein) Lemm. Notas. Est. Inst. Bio. Bar., 26: 1-21.

Simon, N., Brenner, J., Edvardsen, B. \& Medlin, L.K. (1997). The identification of Chrysochromulina and Prymnesium species (Haptophyta, Prymnesiophyceae) using fluorescent or chemiluminescent oligonucleotide probes: a means for improving studies on toxic algae. Eur. J. Phycol., 32 : 393-401.

Sobecky, P.A., Mincer, T.J., Chang, M.C., Toukdarian, A. \& Helinski, D.R. (1998). Isolation of broad-host-range replicons from marine sediment bacteria. Appl. Environ. Microbiol., 64 : 2822-2830.

Sorokin, D.Y. (1995). Sulfitobacter pontiacus gen. nov., sp. nov.: a new heterotrophic bacterium from the Black Sea, specialized on sulfite oxidation. Microbiology (Engl. trans. Mikrobiologiya), 64: 354-365.

StAhl, D.A. \& Amann, R. (1991). Development and application of nucleic acid probes. In Nucleic Acid Techniques in Bacterial Systematics (Stackebrandt, E. \& Goodfellow, M., editors), 205-248. Wiley, New York. Stewart, J.E., Marks, L.J., Wood, C.R., Risser, S.J. \& Gray, S. (1997). Symbiotic relations between bacteria and the domoic acid producing diatom Pseudo-nitzschia multiseries and the capacity of these bacteria for gluconic acid/gluconolactone formation. Aquat. Microb. Ecol., 12: 211-221.

Straub, K.L., Rainey, F.A. \& Widdle, F. (1999). Rhodovulum iodosum sp. nov. and Rhodovulum robiginosum sp. nov., two new marine phototrophic ferrous-iron-oxidizing purple bacteria. Int. J. Syst. Bacteriol., 49: 729-735.

Strunk, O., Gross, O., Reichel, B., May, M., Hermann, S., Stuckmann, N., Nonhoff, B., Lenke, M., Ginhart, A., Vilbig, A., Ludwig, T., Bode, A., SCHLEIFER, K.-H. \& Ludwig, W. (1998). ARB: a software environment for sequence data. http://www.mikro.biologie.tu-muenchen.de/pub/ARB. Department of Microbiology, Technische Universität München, Munich, Germany.

Takami, H., Kobata, K., Nagahama, T., Masui, N., Kobayashi, H., Inoue, A., \& Horikoshi, K. (1998). Biodiversity in deep-sea sites located near the south part of Japan. Extremophiles, 3: 97-102.

Töвe, K., Furgeson, C., Kelly, M., Gallacher, S. \& Medlin, L.K. (2001). Seasonal occurrence at a PSP monitoring site of purportedly toxic bacteria originally isolated from toxic dinoflagellates of the genus Alexandrium. Eur. J. Phycol., in press.

Tosteson, T.R., Ballantine, D.L., Tosteson, C.G., Hensley, V. \& Bardales, A.T. (1989). Associated bacterial flora, growth, and toxicity of cultured benthic dinoflagellates Ostreopsis lenticularis and Gambierdiscus toxicus. Appl. Environ. Microbiol., 55: 137-141.

Uchino, Y., Hirata, A., Yokota, A. \& SugiYama, J. (1998). Reclassification of marine Agrobacterium species: proposals of Stappia stellulata gen. nov., comb. nov., Stappia aggregata sp. nov., nom. rev., Ruegeria atlantica gen. nov., comb. nov., Ruegeria gelatinovora comb. nov., Ruegeria algicola comb. nov., and Ahrensia kieliense gen. nov., sp. nov., nom. rev. J. Gen. Appl. Microbiol., 44: 201-210. 